\title{
Coral disease outbreak: pattern, prevalence and transmission in Acropora cervicornis
}

\author{
Dana E. Williams ${ }^{1,2, *}$, Margaret W. Miller ${ }^{2}$ \\ ${ }^{1}$ Cooperative Institute of Marine and Atmospheric Science, Rosenstiel School of Marine and Atmospheric Science, \\ University of Miami, 4600 Rickenbaker Causeway, Miami, Florida 33149, USA, \\ ${ }^{2}$ NOAA Fisheries, Southeast Science Center, 75 Virginia Beach Drive, Miami, Florida 33149, USA
}

\begin{abstract}
A rapidly progressing disease outbreak affecting Acropora cervicornis (staghorn coral) was recently observed over a wide geographic range $(>200 \mathrm{~km})$ in the Florida Keys, USA. Original observations made at White Bank Dry Rocks revealed colonies with tissue rapidly sloughing from multifocal lesions. Over the course of the epizootic at least $72 \%$ of tagged colonies were affected, live tissue cover of these colonies decreased from $96 \pm 1 \%$ to $12 \pm 5 \%$ (mean $\pm \mathrm{SE}$ ), and $28 \%$ of the colonies suffered complete mortality. Observed rates of tissue loss were highly variable, ranging from 2 to $43 \mathrm{~cm}^{2} \mathrm{~d}^{-1}$, but the mean was a rapid $13 \pm 11 \mathrm{~cm}^{2} \mathrm{~d}^{-1}$ or about $4 \mathrm{~cm}$ branch length $\mathrm{d}^{-1}$. Field experiments demonstrate that this disease is transmissible not only by direct contact between affected and healthy staghorn coral tissue but also by the corallivorous snail Coralliophila abbreviata. The disease was also transmissible, although less effectively so, to the congener A. palmata (elkhorn coral). No transmission was observed in indirect contact treatments designed to simulate diver interaction. Transmissibility implies that the condition is indeed a biotic disease and the demonstration of effective vector transmission suggests that predation may exacerbate disease outbreaks in remnant Caribbean acroporid populations, further impeding their potential recovery.
\end{abstract}

KEY WORDS: Coralliophila abbreviata Predator $\cdot$ Transmission experiment · Vector $\cdot$ Whiteband disease

Resale or republication not permitted without written consent of the publisher

\section{INTRODUCTION}

Since the 1970s, Caribbean acroporids have suffered an estimated $95 \%$ decline in abundance throughout their range (Bruckner 2003) and are being actively considered for listing under the US Endangered Species Act (Anonymous 2005). There is widespread consensus that disease, particularly white band disease (WBD) (Aronson \& Precht 2001), played a dominant role in this dramatic population decline along with increased storm frequency and anthropogenic factors such as increased sediment loading (Aronson et al. 2002, Bruckner 2003).

In April 2003, during a routine monitoring study of Acropora cervicornis growth and survival in the Florida Keys, USA (Williams \& Miller in press), an epizootic was observed at White Bank Dry Rocks $\left(25^{\circ} 02.595^{\prime} \mathrm{N}\right.$, $80^{\circ} 22.156^{\prime} \mathrm{W}_{\text {; }}$ 'White Bank'), a shallow (2 to $3 \mathrm{~m}$ ) patch reef in the Florida Keys National Marine Sanctuary (FKNMS). Many colonies exhibited acute tissue loss manifested as irregular, multifocal lesions along the branches, with apparently healthy tissue remaining in between (Fig. 1). This outbreak resulted in an unprecedented closure of White Bank by FKNMS managers to all recreational and commercial activity (Anonymous 2003) as a precautionary measure to minimize the potential for spread of this disease.

Only 2 diseases are thought to cause tissue loss in natural ${ }^{1}$ populations of Acropora cervicornis (Sutherland et al. 2004): WBD and WBD Type II. Early reports of WBD described its appearance on A. palmata as 'a

\footnotetext{
1.A process termed 'shut-down reaction' involving rapid tissue disintegration at the site of an injury has been described in a few aquarium specimens of Acropora cervicornis (Antonius 1977)
} 


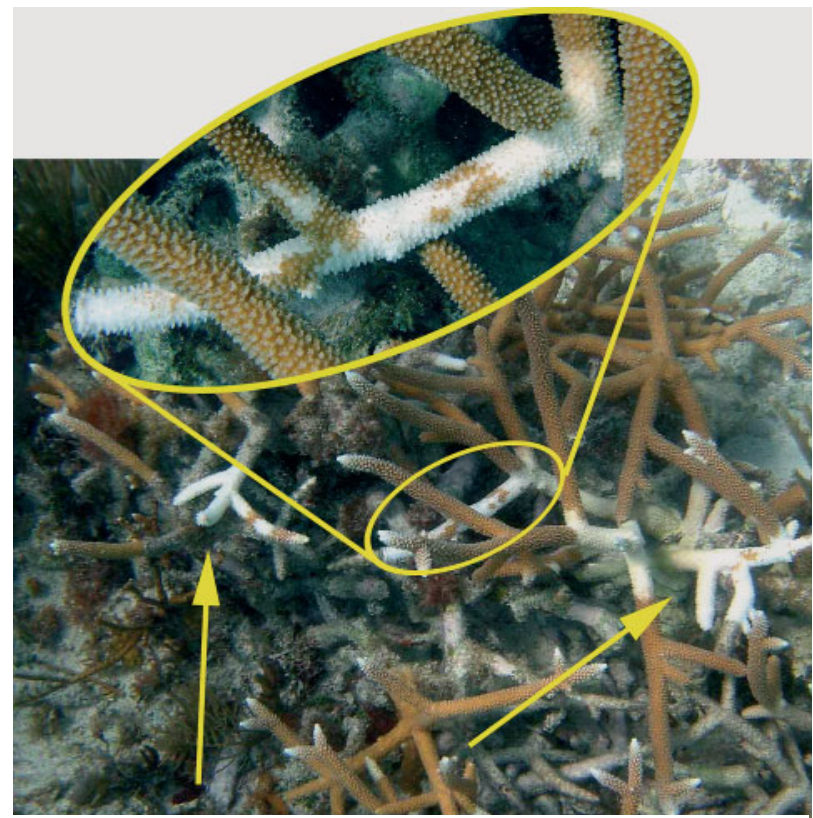

Fig. 1. Acropora cervicornis. Colony showing signs typical of disease at White Bank Dry Rocks. Colony has several discontinuous patches (arrowed) of very recently denuded (bright white) skeleton. Inset: close-up of active tissue loss. Note irregular pattern of tissue sloughing and dead areas. Three days earlier only the basal portion of the colony at the right arrow was newly dead; the inset area and the area at the left arrow appeared completely normal

sharp line of advance where the distally located zooxanthella-bearing coral tissue is cleanly and completely removed from the skeleton, leaving a sharp white zone about $1 \mathrm{~cm}$ wide that grades proximally into algal successional stages' (Gladfelter 1982). Reported rates of advance on $A$. palmata average $5.5 \mathrm{~mm} \mathrm{~d}^{-1}$ (Gladfelter 1982), but range from 2 to $20 \mathrm{~mm} \mathrm{~d}^{-1}$ (Antonius 1981). In contrast, published descriptions of WBD on the congener, A. cervicornis, are highly variable and far less detailed; it is typically described as a white band of skeleton occurring in the middle of live branches (Peters et al. 1983, Santavy \& Peters 1997), but neither its progression rate or pattern have been reported. In fact, recent tissue loss affecting $A$. cervicornis that cannot be attributed to predation has frequently been attributed to WBD regardless of the rate and pattern of progression (Aronson et al. 2002, Precht et al. 2002). The etiology of WBD has not yet been confirmed (Peters et al. 1983, Santavy et al. 1995, Richardson 1998) nor has it been demonstrated to be the same in both $A$. cervicornis and A. palmata (Santavy \& Peters 1997). Moreover, Ritchie \& Smith (1995) described WBD in A. cervicornis with a margin of bleached tissue preceding the margin of tissue loss, further complicating recognition of WBD in A. cervicornis. The disease described by Ritchie \& Smith (1995) has since been more specifically named WBD Type II, and is believed to be a separate disease associated with Vibrio charcharia bacteria (Ritchie \& Smith 1998). Because the gross disease signs observed at White Bank are not consistent with either type of WBD, we will refer to it simply as 'rapid tissue loss' (Fig. 1) for the purposes of discussion. Although the cause of rapid tissue loss is unknown, the term 'disease' will be used in accordance with its common definition-'any impairment (interruption, cessation, proliferation, or other disorder) of vital body functions, systems, or organs' (Sutherland et al. 2004).

Over the past 2 decades, many new coral diseases have emerged (Goreau et al. 1998, Harvell et al. 1999). Despite extensive investigation, few of these diseases have been characterized beyond visual description of disease signs and even fewer have been associated with a pathogen that satisfies Koch's postulates (Richardson 1998). Although identification of the causal agent(s) is typically the first question asked following an outbreak, it remains one of the most elusive aspects of coral disease epizootiology. The Coral Disease and Health Consortium (CDHC) has published a national research plan (Woodley et al. 2003) that calls for ecological characteristics such as gross morphology (disease signs), incidence, prevalence or modes of transmission in addition to pathogen identification to fully characterize a coral disease. Even without identification of the causal agent, knowledge of these ecological attributes would permit rigorous in situ assessment of disease impact(s) on field populations and may enable resource managers to design effective mitigation strategies. For example, in the fight against yellow fever in humans, the mode of transmission (mosquito vector) was elucidated through field experiments (Finlay 2001) and effective control measures were implemented prior to the identification of the viral pathogen (McCarthy 2001).

Although an investigation to identify a specific pathogen associated with rapid tissue loss is currently underway (coordinated by the CDHC), herein we report field observations and experiments. These observations indicate key ecological traits such as gross lesion morphology, rates of progression, and the incidence, prevalence, and distribution of affected colonies. Field transmission experiments testing direct and indirect tissue contact as well as a potential vector were undertaken to determine if the rapid tissue loss observed at White Bank should be regarded as a transmissible disease.

\section{MATERIALS AND METHODS}

Field surveys. White Bank is a shallow patch reef situated $6 \mathrm{~km}$ off Key Largo, Florida, in approximately $6 \mathrm{~m}$ of water. The top of this patch reef, at a depth of 2 
to $3 \mathrm{~m}$, has a relatively sparse population of small Acropora cervicornis colonies interspersed with small head corals (Diploria spp, Porites spp. and Montastraea annularis) and gorgonians. In June 2002, 19 colonies of A. cervicornis were haphazardly chosen and tagged for periodic monitoring. Colony condition was assessed by visually estimating the percentage of each colony that was covered with live tissue (hereafter '\% live'). Colonies were re-surveyed on November 21, 2002 and April 17, 2003, when rapid tissue loss was observed. Thereafter, tagged colonies were surveyed more frequently (April 29, 2003 and May 13, 2003) to track the short-term trends of this outbreak, and then were not surveyed again until February 4, 2004. Prevalence of disease (i.e. proportion of tagged colonies with rapid tissue loss) was determined at each census. Transect surveys conducted in the vicinity of the tagged colonies confirmed similar trends among the surrounding population between summer 2002 and April 2003 (authors' unpubl. data).

Qualitative surveys of Acropora cervicornis (and, at 1 site, A. prolifera, an F1 hybrid of A. palmata and $A$. cervicornis: Vollmer \& Palumbi 2002) populations were made between May 2003 and August 2003 at 17 sites over a wide geographic range from Biscayne National Park to Dry Tortugas National Park including the FKNMS (Table 1). Sites with known A. cervicornis occurrence were targeted because of its extremely patchy and sparse distribution. Surveys were based on a single visit when the prevalence of rapid tissue loss was ranked as high ( $>40 \%$ of colonies affected), moderate (10 to $40 \%)$ or low $(<10 \%)$ for each site. For sites where signs of rapid tissue loss were observed but fewer than 10 colonies were found, prevalence was conservatively ranked as low.

Transmission experiments. We conducted 4 separate controlled experiments at White Bank, in the vicinity of the tagged colonies at 2 to $3 \mathrm{~m}$ depth, to determine if the condition was transmissible. Loose, apparently healthy, fragments of Acropora cervicornis found at White Bank were collected and allocated to 1 of 3 experiments. For an additional experiment, fragments of $A$. palmata were imported from other sites (see Expt II below). Latex gloves were worn and changed between handling of replicates to minimize cross-contamination.

Each experiment was run in 2 trials, with the second trial undertaken to improve treatment exposure in the direct and indirect contact experiments (see following subsections) and to increase replication (see Table 2 for sample sizes) in the predator experiment. In each trial, the replicates were checked for response (defined as the observation of tissue sloughing) every 2 to $6 \mathrm{~d}$ for a period of $3 \mathrm{wk}$. Frequencies of positive (disease) responses among treatments (healthy control and dis- ease exposed) at the end of each $3 \mathrm{wk}$ trial were analyzed using Fisher's exact 1-tailed test $(\alpha=0.05$; StatSoft 2001).

In replicates that responded, response time was calculated from the day of setup (Day 0) to the day that tissue sloughing was first observed. For the predator feeding treatments (see last subsection below), Day 0 was considered as the day the feeding scar was first observed and was at least $2 \mathrm{~d}$ (range 1 to $3 \mathrm{~d}$ ) after the snail had been placed on the fragment.

Area of tissue loss was estimated from scaled photographs of 17 time intervals of 10 fragments with disease response in Expts I and IV (see following subsections). Image analysis software (Image Tool Version 3.0, UTHSCSA) was used to measure the length and diameter of the areas with tissue loss, and a surface area was calculated based on the formula for an openended cylinder $(\pi \mathrm{dh})$. The rate of tissue loss $\left(\mathrm{cm}^{2} \mathrm{~d}^{-1}\right)$ was calculated using the number of days between photographs.

Expt I. Acropora cervicornis direct contact: Apparently healthy $A$. cervicornis fragments were attached in direct contact with healthy and diseased A. cervicornis colonies. Fragments were affixed using cable ties to branches with actively sloughing tissue ('treatment') or branches of apparently entirely healthy ('control'), standing A. cervicornis host colonies. Of the 6 treatment fragments in the first trial, 3 were repositioned after $10 \mathrm{~d}$ because the disease front on the host colony had either lost contact with the fragment or appeared inactive. Fragments in the second trial were more accurately positioned on the host branches using additional cable ties to effect more consistent contact with the diseased branch, so repositioning was not necessary. Because the number of colonies with active disease in the surrounding population had diminished by the second trial, it was necessary to place more than 1 fragment on a single standing host colony, but replicates were always on separate branches.

Expt II. Acropora palmata direct contact: No $A$. palmata fragments were available at White Bank, so apparently healthy fragments were collected from Sand Island reef $\left(25^{\circ} 01.107 \mathrm{~N}, 80^{\circ} 22.044 \mathrm{~W}\right)$ for the first trial and Little Grecian reef $\left(25^{\circ} 07.220 \mathrm{~N}, 80^{\circ} 18.050 \mathrm{~W}\right)$ for the second trial. These fragments were attached to diseased ('treatment') or healthy ('control') A. cervicornis colonies at White Bank using cable ties. In some cases, the size or shape of the A. palmata fragment made it impossible to attach to a standing $A$. cervicornis colony. In these cases, the $A$. palmata fragments were stabilized on the substrate using cable ties and a treatment (diseased) or control (apparently healthy) A. cervicornis fragment was cable tied to make direct contact between the fragments. As with Expt I, fragments were more carefully positioned on control and treatment 
branches with additional cable ties to achieve more consistent contact in the second trial.

Expt III. Indirect contact: Apparently healthy Acropora cervicornis fragments were stabilized to the substrate using cable ties, then swabbed by latex-gloved hand that had been swabbed on either diseased ('treatment') or healthy ('control') A. cervicornis tissue immediately beforehand. This experiment was intended to simulate diver interaction. In the second trial, both the control and treatment fragments were swabbed more forcefully than in the first trial so that visible but minor mechanical tissue damage was inflicted during the attempted inoculation.

Expt IV. Predator feeding: Apparently healthy Acropora cervicornis fragments were stabilized to the substrate as in Expt III. Coralliophila abbreviata (short coral snail) that were found feeding on diseased ('treatment snails') or healthy ('control snails') A. cervicornis colonies were then

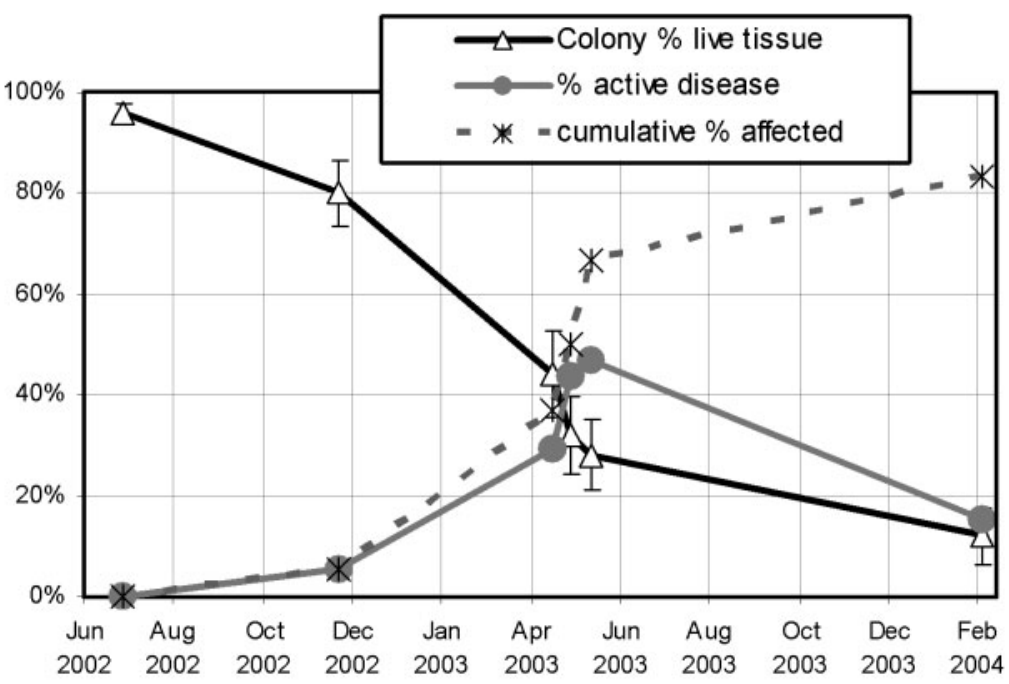

Fig. 2. Acropora cervicornis. Assessment of tagged colonies $(n=19)$ from White Bank Dry Rocks during monitoring period (June 2002 to February 2004) showing changes in estimated percentage of a colony covered by live tissue (mean $\pm \mathrm{SE}$ ), the percentage of live tagged colonies with active signs of disease, and the cumulative percentage observed affected by disease at some point, including those then completely dead or in which disease was recrudescent (not active)

allowed to feed on a stabilized fragment.

Once the snail had created a noticeable feeding scar, it was removed (usually after $2 \mathrm{~d}$ ), and the fragment was monitored for disease signs. Both trials of this experiment were identical in procedure, so the responses were pooled for analysis.

\section{RESULTS}

\section{Field surveys}

The fate of the tagged colonies at White Bank is illustrated in Fig. 2. During the baseline period (June to November 2002), a few colonies showed typical signs of predation by Hermodice carunculata (fireworm) and Coralliophila abbreviata; 1 colony was nearly killed by unknown causes, and 1 colony displayed rapid tissue loss. During April to May 2003, an average of 1 new colony (5\% of tagged) $\mathrm{wk}^{-1}$ became affected by rapid tissue loss and 3 colonies died completely. By the final census (February 2004), a total of 5 colonies were completely dead and, of the 13 remaining colonies with live tissue (1 was lost), 2 still showed active signs of rapid tissue loss. During the course of the outbreak, a total of 13 colonies had been directly observed to be affected by rapid tissue loss. Of the 5 colonies that were not directly observed with disease signs, 2 were dead and the other 3 had less than $10 \%$ live tissue cover, suggesting that they had indeed been affected by rapid tissue loss at some point.
Rapid tissue loss was observed on Acropora cervicornis colonies at 13 out of the 17 sites surveyed throughout the Florida Keys (Fig. 3, Table 1). Of these, 6 sites were considered to have high to moderate prevalence $(>10 \%)$ of colonies showing rapid tissue loss (Fig. 3).

\section{Transmission experiments}

No control replicates showed disease response in any of the 4 experiments. The first trial of each direct contact experiment (Expts I and II) produced a response but it was not statistically significant (Table 2). Our observations suggested that non-responding replicates often had not maintained consistent contact with the actively diseased area. In the second trials of Expts I and II, more replicates responded and response was faster, suggesting that direct tissue contact was important in transmission. The second trial of Expt I yielded significant response ( $p=0.0455)$. In Expt II, transmission did occur in 3 of 5 second trial treatment replicates, although it was not statistically significant $(\mathrm{p}=0.2857)$. Once rapid tissue loss was transmitted to Acropora palmata (Expt II), signs were identical in appearance to those in A. cervicornis, namely irregular tissue sloughing with no resemblance to a band (Fig. 4).

Indirect contact (Expt III) failed to produce disease signs in any of the treatment or control replicates, even in the second trial where tissue was clearly injured by the swabbing. In contrast, feeding by treatment snails 


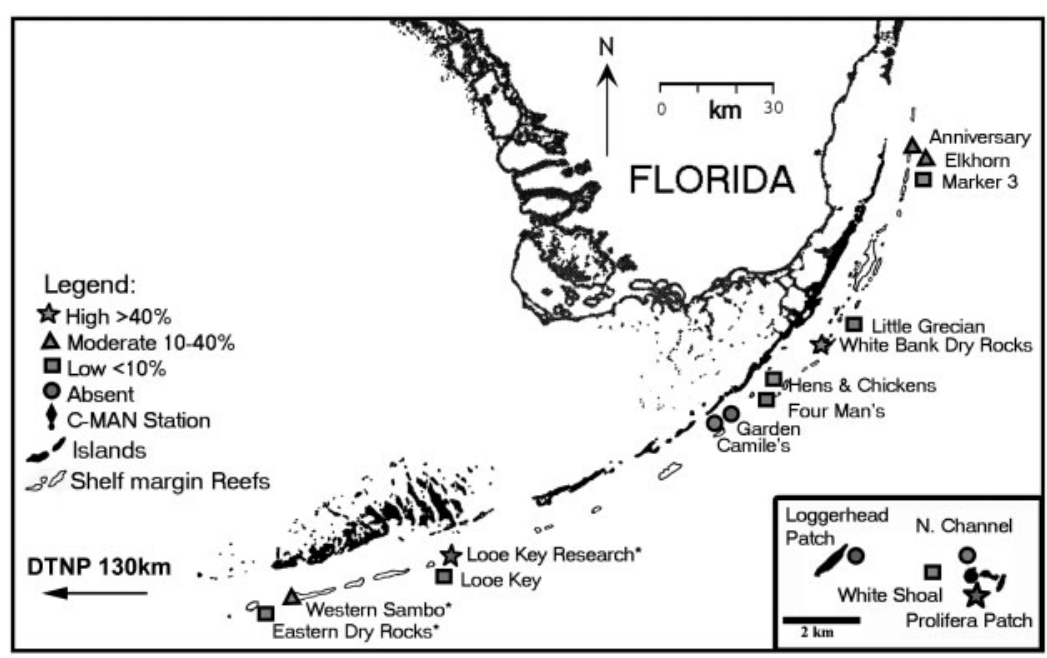

Fig. 3. Florida Keys reef tract showing sites with Acropora cervicornis that were visited between April and August 2003 (see Table 1). Legend symbols: qualitative assessment of disease prevalence; inset map: sites within Dry Tortugas National Park (DTNP) around Garden and Loggerhead Keys located approximately $130 \mathrm{~km}$ west of Key West. *: observations reported to Mote Marine Laboratory's Marine Ecosystem Event Response and Assessment (MEERA) program

(Expt IV; Fig. 5) produced a significant response (Table 2; $\mathrm{p}=0.034,2$ trials pooled since they were identical in method).

Among fragments that responded to the treatments, the response occurred within as little as $2 \mathrm{~d}$ but in some cases took longer than 1 wk (Table 2). Fragments exposed to treatment snails responded the fastest and

Table 1. Sites (see Fig. 3) in the Florida Keys with Acropora cervicornis visited between April and August 2003, listed in order of visit

\begin{tabular}{|c|c|c|c|c|}
\hline $\begin{array}{l}\text { Site } \\
\text { no. }\end{array}$ & $\begin{array}{l}\text { Site } \\
\text { name }\end{array}$ & $\begin{array}{c}\text { Date 1st } \\
\text { visited }\end{array}$ & $\begin{array}{l}\text { Latitude } \\
\text { (N) }\end{array}$ & $\begin{array}{l}\text { Longitude } \\
\text { (W) }\end{array}$ \\
\hline 1 & White Bank & 17 Apr & $25^{\circ} 02.595$ & $80^{\circ} 22.156$ \\
\hline 2 & Elkhorn Reef & 4 May & $25^{\circ} 21.688$ & $80^{\circ} 09.922$ \\
\hline 3 & Anniversary Reef & 4 May & $25^{\circ} 23.233$ & $80^{\circ} 09.917$ \\
\hline 4 & Little Grecian & 12 May & $25^{\circ} 07.220$ & $80^{\circ} 18.050$ \\
\hline 5 & Marker 3 & 6 Jun & $25^{\circ} 22.395$ & $80^{\circ} 09.614$ \\
\hline 6 & Eastern Dry Rocks ${ }^{a}$ & 7 Jun & $24^{\circ} 27.550$ & $81^{\circ} 50.700$ \\
\hline 7 & Prolifera Patch ${ }^{b}$ & 8 Jun & $24^{\circ} 37.234$ & $82^{\circ} 52.166$ \\
\hline 8 & White Shoal & 8 Jun & $24^{\circ} 38.484$ & $82^{\circ} 53.769$ \\
\hline 9 & Looe Key ${ }^{\mathrm{a}}$ & 10 Jun & $24^{\circ} 32.950$ & $81^{\circ} 24.050$ \\
\hline 10 & Looe Key Research ${ }^{\mathrm{a}}$ & 10 Jun & $24^{\circ} 33.050$ & $81^{\circ} 24.500$ \\
\hline 11 & Western Sambo ${ }^{a}$ & 14 Jun & $24^{\circ} 28.780$ & $81^{\circ} 42.799$ \\
\hline 12 & Loggerhead & $23 \mathrm{Jul}$ & $24^{\circ} 38.104$ & $82^{\circ} 54.964$ \\
\hline 13 & North Channel & $23 \mathrm{Jul}$ & $24^{\circ} 37.919$ & $82^{\circ} 52.317$ \\
\hline 14 & Four Man's Reef & $31 \mathrm{Jul}$ & $24^{\circ} 53.444$ & $80^{\circ} 32.724$ \\
\hline 15 & Camile's Reef & $31 \mathrm{Jul}$ & $24^{\circ} 53.628$ & $80^{\circ} 34.657$ \\
\hline 16 & The Garden & $31 \mathrm{Jul}$ & $24^{\circ} 53.700$ & $80^{\circ} 34.348$ \\
\hline 17 & Hen \& Chickens & $31 \mathrm{Jul}$ & $24^{\circ} 56.253$ & $80^{\circ} 32.839$ \\
\hline \multicolumn{5}{|c|}{$\begin{array}{l}\text { abservations reported to Mote Marine Laboratory's } \\
\text { Marine Ecosystem Event Response and Assessment } \\
\text { (MEERA) program } \\
\text { b Thicket of A. prolifera (hybrid of A. cervicornis and } \\
\text { A. palmata) }\end{array}$} \\
\hline
\end{tabular}

most consistently, while the direct contact treatments were more variable in response time. Rates of tissue loss ranged from 2 to $43 \mathrm{~cm}^{2} \mathrm{~d}^{-1}$ with a mean of $13 \pm$ $11 \mathrm{~cm}^{2} \mathrm{~d}^{-1}$ (mean $\pm \mathrm{SD}$ ). This wide range in progression rate further illustrates the recrudescent tendency of this disease.

\section{DISCUSSION}

\section{Experimental response}

Our experiments demonstrate the transmission of disease signs inconsistent with allograft (intra-specific; Expt I) and xenograft (inter-specific; Expt II) rejection responses (Hildemann et al. 1977). Graft rejection responses typically result in blanching of tissue followed by tissue loss limited to the immediate area of contact (Hildemann et al. 1977) and would only be expected to occur after 2 to $3 \mathrm{wk}$ or more of direct contact. Even though our experiments lasted $3 \mathrm{wk}$, disease response typically occurred within a few days, and was characterized by tissue loss well beyond the area of contact (in most cases the entire fragment died).

Variability in response and response time among replicates was not unexpected and probably resulted from several factors. Treatment (diseased) host colonies or snails were chosen for the presence of active tissue sloughing and occurrence on a colony with active tissue sloughing, respectively. These gross signs may be imperfect proxies for disease 'activity', virulence, or effective vector inoculation. Occasionally, the host disease front would stall for a few days or even indefinitely. In such cases, transmission seemed to occur only after the host disease front became active again. For example, the exceptionally long response time (12 d, Table 2) of one Expt I replicate was probably due to a $6 \mathrm{~d}$ pause in the host's disease progression. Diseaseresistant genets may have existed, which could explain differential susceptibility even among identically treated replicates. Since loose fragments were used in these experiments, there is no way of estimating how many unique genets were involved. Additionally, variability in the immune response may also account for different responses among the replicates.

It is interesting that indirect contact did not transmit the disease, despite aggressive application. It may be that a longer duration of exposure (such as the direct contact treatments) or complete tissue breach (as with a feeding scar) is required for transmission to be effective in a fluid medium. Unlike the surface of the latex 

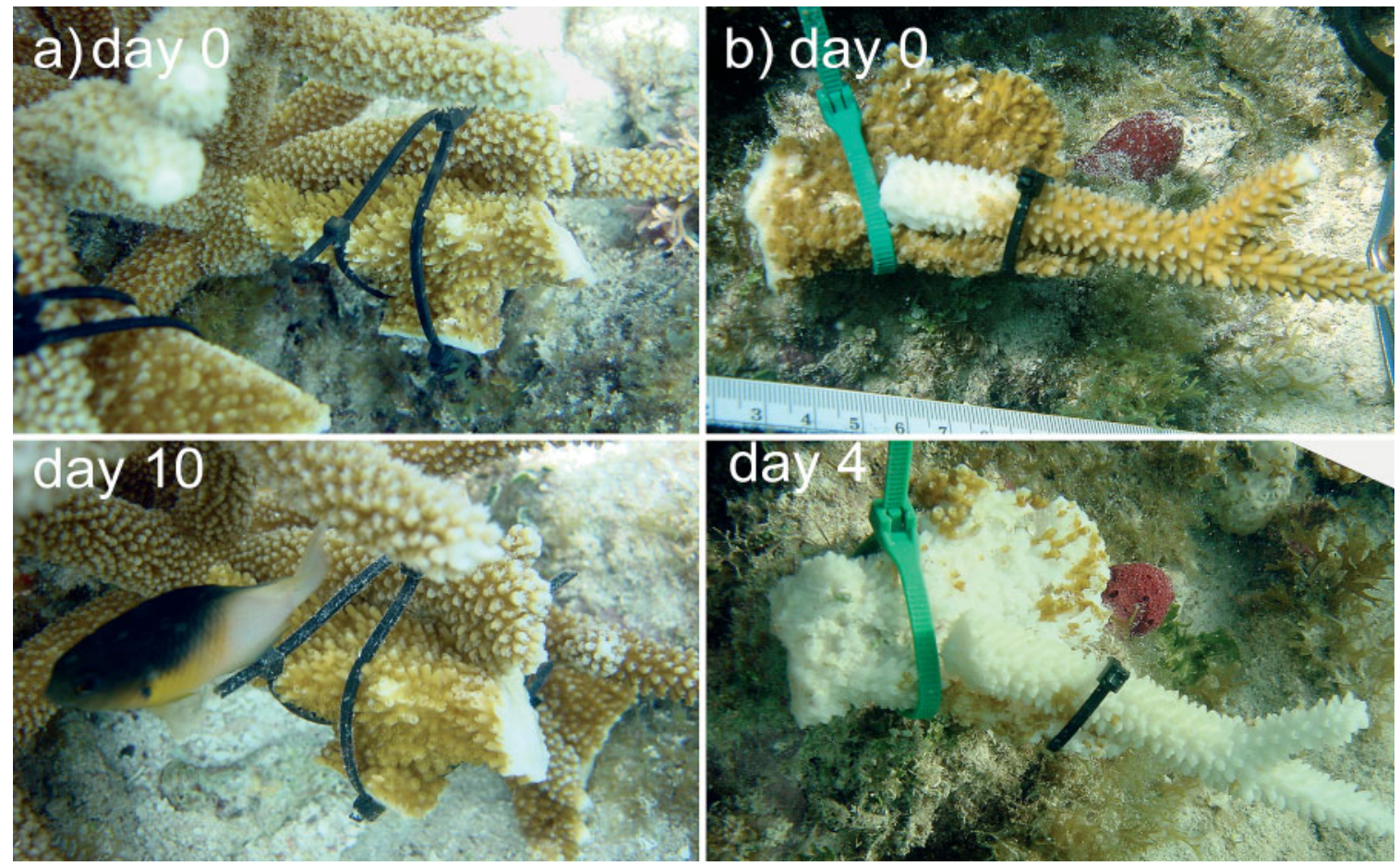

Fig. 4. Acropora palmata. Healthy fragment in direct contact with (a) healthy and (b) diseased A. cervicornis fragments in Expt II. At initial setup (Day 0) both treatments were healthy; 4 d later the $A$. palmata fragment in the disease-exposed treatment is almost completely dead. Note the sloughing tissue on A. palmata does not form 'band-like' appearance typical of white band disease

gloves which was exposed to the water column in the indirect inoculation (Expt III), snails may have effectively retained the transmissive agent by withdrawing their guts (which are everted when feeding, Ward 1965) during transfer from the inoculation colony to the treatment fragment.

\section{Acute stress?}

Tissue sloughing similar to that seen at White Bank has been associated with acute environmental stress.
In 1977, Acropora cervicornis populations in the Dry Tortugas rapidly sloughed live tissue following an extreme cold front when temperatures dropped to $14^{\circ} \mathrm{C}$ (Davis 1982), suggesting that the condition at White Bank could have resulted from physiological stress in response to anomalous water temperatures or other environmental factors. However, colonies continued to become affected at a high rate throughout the spring and summer outbreak of 2003 (Figs. 2 \& 3), a few colonies manifested active disease in winter (February 2004, Fig. 2), and many diseased A. cervicornis colonies were observed at White Bank in

Table 2. Acropora cervicornis (AC) and Acropora palmata (Ap). Results of Expts I to IV (Trials 1 and 2); n: number of replicates; $\mathrm{R}$ : number of replicates showing disease response (subscripted numbers are trial numbers); $\mathrm{R}$ time: range in response time, or number of days from the initial exposure to the first sign of disease for all responding replicates; na: not applicable. Responses were compared using Fisher's exact test; p-values are shown for each trial. Trials 1 and 2 of Expt IV were pooled since methods were identical

\begin{tabular}{|c|c|c|c|c|c|c|c|c|c|}
\hline \multirow{2}{*}{ Expt } & \multirow{2}{*}{ Treatment } & & & \multicolumn{2}{|c|}{ Trial 1} & 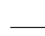 & & \multicolumn{2}{|l|}{ Trial 2} \\
\hline & & $\mathrm{n}_{1}$ & $\mathrm{R}_{1}$ & R time $(\mathrm{d})$ & $\mathrm{p}_{1}$ & $\mathrm{n}_{2}$ & $\mathrm{R}_{2}$ & $\mathrm{R}$ time $(\mathrm{d})$ & $\mathrm{p}_{2}$ \\
\hline \multirow{2}{*}{$\begin{aligned} & \text { I, } A C: \text { direct } \\
& \text { contact }\end{aligned}$} & Control & 3 & 0 & na & \multirow[t]{2}{*}{0.416} & 3 & 0 & na & \multirow[t]{2}{*}{0.045} \\
\hline & Diseased & 6 & 2 & $7-12$ & & 9 & 7 & $2-7$ & \\
\hline \multirow{2}{*}{$\begin{array}{l}\text { II, } A p: \text { direct } \\
\text { contact }\end{array}$} & Control & 3 & 0 & na & \multirow[t]{2}{*}{0.500} & 2 & 0 & na & \multirow[t]{2}{*}{0.286} \\
\hline & Diseased & 3 & 1 & 6 & & 5 & 3 & $3-10$ & \\
\hline \multirow{2}{*}{$\begin{array}{r}\text { III, } A C: \text { indirect } \\
\text { contact }\end{array}$} & Control & 3 & 0 & na & \multirow[t]{2}{*}{ na } & 1 & 0 & na & \multirow[t]{2}{*}{ na } \\
\hline & Diseased & 3 & 0 & na & & 3 & 0 & na & \\
\hline \multirow[t]{2}{*}{ IV, $A C$ : predator } & Control & 3 & 0 & na & \multirow[t]{2}{*}{ pooled } & 3 & 0 & na & \multirow[t]{2}{*}{0.034} \\
\hline & Diseased & 7 & 4 & $2-5$ & & 6 & 3 & $2-3$ & \\
\hline
\end{tabular}


Fig. 5. Acropora cervicornis Time series showing typical (a) control and (b) treatment replicates for Expt IV, in which experimental coral fragments were fed upon by C. abbreviata snails (Sn) collected from nearby healthy (control, Fig. 5a) and diseased (treatment, Fig. 5b) colonies. Day 0: snails feeding at the base of each fragment. Days 2 and 4: snails have been removed and fresh feeding scars (FS) can be seen. Fragment fed on by control snail (a) remained healthy throughout experiment. Fragment fed on by the treatment snail (b) had tissue rapidly sloughing from the feeding scar by Day 7 and tissue loss over two-thirds of the fragment by Day 9 . This represents average tissue loss of $\sim 4 \mathrm{~cm}$ branch length $\mathrm{d}^{-1}$ or $21 \mathrm{~cm}^{2}$ tissue $\mathrm{d}^{-1}$ (based on Days 4 to 9; scale in Day 4 frame). Note in the treatment series (b) that the original feeding scar attains a progressively darker tinge as algal colonization proceeds, making it possible to distinguish it from the more recently disease-killed area
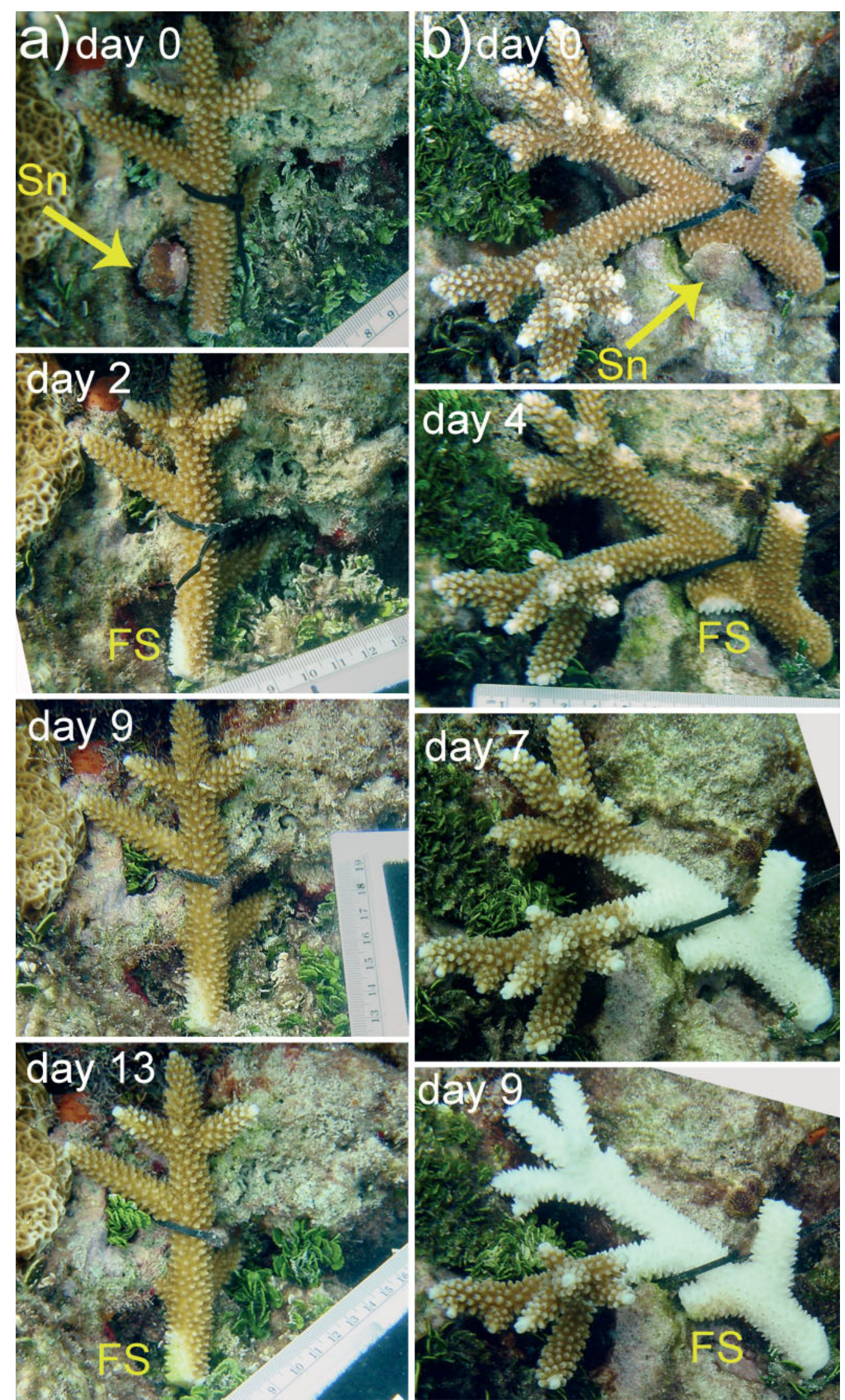
summer 2004 (D. E. Williams pers. obs.). The sustained and ongoing nature of the epizootic and the persistence of active disease signs under a range of seasonal conditions, indicate that the rapid tissue loss of $A$. cervicornis observed at White Bank (and probably at other sites in the Florida Keys, Fig. 3) resulted from a biotic, transmissible disease, rather than an acute physiological stress response to environmental factors. There remains the possibility that subtle environmental stresses may have influenced pathogen virulence and/or host susceptibility in the onset of the outbreak.

\section{White band disease?}

The average rate of tissue loss for the disease observed in this study was estimated to be $13 \pm 11 \mathrm{~cm}^{2}$ $\mathrm{d}^{-1}$ (mean $\pm \mathrm{SD}$ ), or $4 \mathrm{~cm} \mathrm{~d}^{-1}$ when translated to a linear progression rate on a typical branch. Compared to the average progression rate of WBD in Acropora palmata (Gladfelter 1982), linear progression of rapid tissue loss is almost 1 order of magnitude greater. Unlike Gladfelter's (1982) description of a proximal gradation of algal colonization on WBD-denuded skeleton, we observed relatively large (several entire branches) areas of exposed skeleton with uniform degrees of algal colonization, indicating that the entire area lost tissue at approximately the same time. Often a single colony would have several of these large segments, each at different algal successional stages. In contrast to WBD, these large patches with homogeneous algal growth demonstrate that tissue loss was rapid but occasionally recrudescent.

Furthermore, the cases of experimental transmission of rapid tissue loss from Acropora cervicornis to A. palmata (Expt II) did not result in the distinctive signs typical of WBD in A. palmata (Gladfelter 1982). Rather, the infected $A$. palmata fragments sloughed tissue from large patches at a time (Fig. 4). This pattern resembles white pox, which was recently associated with the bacterial pathogen Serratia marcescens and said to affect only A. palmata (Patterson et al. 2002). White pox produces scattered lesions that remove up to $12 \mathrm{~cm}^{2}$ (mean $2.5 \mathrm{~cm}^{2}$ ) of live tissue $\mathrm{d}^{-1}$ (Patterson et al. 2002). Also, given the patchy and rapid progression of tissue loss observed in A. cervicornis affected by rapid tissue loss at White Bank (Fig. 1), 'white band disease' would be a misnomer.

While the rapid tissue loss we describe here is not consistent with WBD, we are not suggesting it is a 'new' disease. Bak \& Criens (1981) described very similar disease signs affecting both Acropora cervicornis and $A$. palmata in Curaçao. In a field experiment designed to document the effects of fragmentation, they observed 'white spots on [Acropora spp.] coral branches...which enlarged through necrosis. [In $A$. cervicornis]...necrosis spread rapidly over the branches and fragments completely covered with living tissue (length $20 \mathrm{~cm}$ ) were commonly found wholly dead one week later'. Because their report roughly coincided with the first descriptions of WBD, it was probably assumed to be WBD (Green \& Bruckner 2000). However, Bak \& Criens' (1981) description of disease signs on $A$. cervicornis is strikingly similar to that reported herein and to published reports of A. palmata afflicted with white pox (Rodríguez-Martínez et al. 2001, Patterson et al. 2002, Sutherland et al. 2004).

\section{Vectors in coral disease}

A link between snail predators and disease spread has been suggested by other studies. For example, an outbreak of 'white syndrome' in Red Sea acroporid corals was correlated with an outbreak in the corallivorous snail Drupella cornus (Antonius \& Reigl 1997). We have shown for the first time in a field setting that the corallivorous snail Coralliophila abbreviata is capable of transmitting coral disease. These snail predators are common on acroporid corals in Florida (Miller et al. 2002) and many areas of the Caribbean (e.g. Knowlton et al. 1990, Bruckner et al. 1997) (authors' unpubl. data).

Exposure to Hermodice carunculata (polychaete) infected with the bleaching pathogen Vibrio shiloi has been shown to induce bleaching in the Mediterranean coral Oculina patagonica in laboratory aquaria (Sussman et al. 2003). H. carunculata is also a common predator of Acropora cervicornis in the Florida Keys; it feeds by engulfing a branch tip and digesting the coral tissue, leaving bare skeleton behind (Marsden 1962). This polychaete is a highly mobile predator with a crepuscular feeding habit (Marsden 1962), and hence not amenable to experimental manipulation in the field. However, because it is far more mobile than the snail used in our experiment, it would make a more effective vector if it were capable of vectoring this disease. Nevertheless, it is unlikely that either of these predators travel between reef sites, so additional modes of transmission probably exist, based on the observation of rapid tissue loss from $A$. cervicornis throughout the Florida reef tract (Fig. 3).

Apart from predator outbreaks such as those seen in the Indo-Pacific (Cameron et al. 1991), the effects of corallivores are generally thought to be limited and localized due to their relatively low densities and limited mobility (Carpenter 1997, Reyes-Bonilla \& Calderon-Aguilera 1999). However, demonstration that corallivorous snails can transmit a virulent coral disease in the field suggests that the potential effects of 


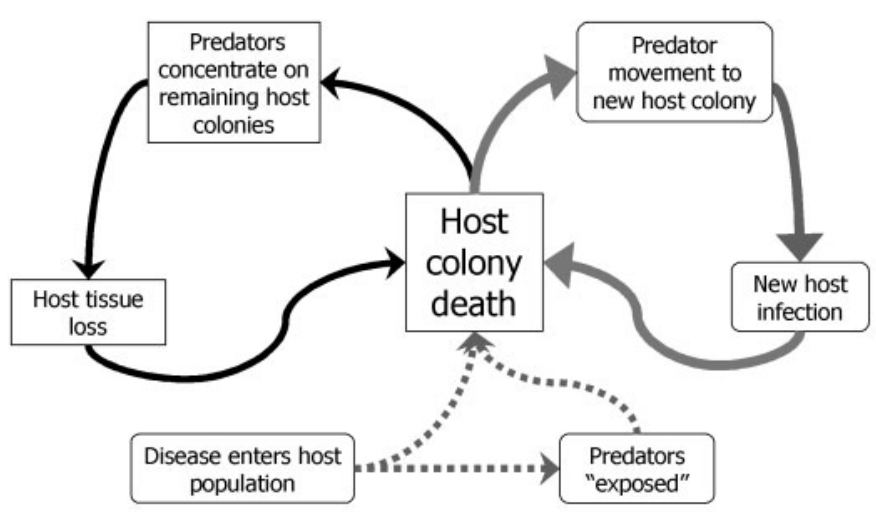

Fig. 6. Potential feedback processes associated with corallivores vectoring coral diseases. Left loop illustrates previously documented patterns of predator concentration on remnant Acropora spp. populations in the Caribbean (Knowlton et al. 1990, Baums et al. 2003). Introduction of a disease that can be vectored to the host population may result in exposure of predators to the disease agent and initiate an additional interactive feedback loop (right loop) resulting in escalation of coral loss

corallivory have not been fully recognized (Fig. 6). Previous studies have shown that Coralliophila abbreviata snails concentrate on remnant Acropora spp. stands after a coral die-off (Knowlton et al. 1990, Baums et al. 2003), implying that when their host dies they move to another host of the same species. Concentration of these predators on the remaining colonies would logically result in greater tissue loss from their feeding activity (Fig. 6, left loop). If disease is introduced to the host population, the predator may become 'exposed' to the transmissive agent as it feeds on a diseased host's tissue. As obligate corallivores, mortality of their host from whatever cause requires snails to forage for a new coral host (Fig. 6, right loop) and, based on our findings, infection of nearby colonies may result, thereby initiating an additional interacting 'disease loop' exacerbating host coral loss. In other words, the results of the current study suggest a positive feedback whereby predator concentration (Knowlton et al. 1990, Baums et al. 2003) and increased foraging resulting from rapid Acropora spp. loss may exacerbate disease outbreaks, further threatening Acropora spp. recovery in the Caribbean.

Acknowledgements. This work was supported by the Southeast Fisheries Science Center under the NOAA Fisheries Coral Reef Conservation Program. We thank the Florida Keys National Marine Sanctuary, Biscayne National Park, Dry Tortugas National Park, and L. Lawrence for logistical support. We thank I Baums, D. Harvell, B. Keller, C. Woodley and several anonymous reviewers for valuable comments. We thank R. Appugliese, C. Fasano and L. Lawrence for field assistance. Field experiments were performed under permit number FKNMS 2002-084.

\section{LITERATURE CITED}

Anonymous (2003) Florida Keys National Marine Sanctuary: establishment of temporary no-entry zone in the White Bank Dry Rocks area. Fedl Register 68(126):39005-39006

Anonymous (2005) Endangered and threatened species; proposed threatened status for elkhorn coral and staghorn coral. Fedl Register 70(88):24359-24365

Antonius A (1977) Coral mortality in reefs: a problem for science and management. Proc 3rd Int Coral Reef Symp 2: 618-623

Antonius A (1981) The 'band' diseases in coral reefs. Proc 4th Int Coral Reef Symp 2:7-14

Antonius A, Riegl B (1997) A possible link between coral diseases and a corallivorous snail (Drupella cornus) outbreak in the Red Sea. Atoll Res Bull 447:2-9

Aronson RB, Precht WF (2001) White-band disease and the changing face of Caribbean coral reefs. Hydrobiologia 460:25-38

Aronson RB, Macintyre IG Precht WF, Murdoch TJT, Wapnick CM (2002) The expanding scale of species turnover events on coral reefs in Belize. Ecol Monogr 72:233-249

Bak RPM, Criens SR (1981) Survival after fragmentation of colonies of Madracis mirabilis, Acropora palmata and A. cervicornis (Scleractinia) and the subsequent impact of a coral disease. Proc 4th Int Coral Reef Symp 2:221-227

Baums IB, Miller MW, Szmant AM (2003) Ecology of a corallivorous gastropod, Coralliophila abbreviata, on 2 scleractinian hosts. I. population structure of snails and corals. Mar Biol 142:1083-1091

Bruckner AW (2003) Proceedings of the Caribbean Acropora Workshop: potential application of the US Endangered Species Act as a conservation strategy. NOAA Tech Memo NMFS OPR-24:184

Bruckner RJ, Bruckner AW, Williams EH Jr (1997) Life history strategies of Coralliophila abbreviata Lamarck (Gastropoda: Coralliophilidae) on the southwest coast of Puerto Rico. Proc 8th Int Coral Reef Symp1:627-632

Cameron AM, Endean R, DeVantier LM (1991) Predation on massive corals: Are devastating population outbreaks of Acanthaster planci novel events? Mar Ecol Prog Ser 75: 251-258

Carpenter RC (1997) Invertebrate predators and grazers. In: Birkeland C (ed) Life and death of coral reefs. Chapman \& Hall, New York, p 198-229

Davis GE (1982) A century of change in coral distribution at the Dry Tortugas: a comparison of reef maps from 1881 and 1976. Bull Mar Sci 32:608-623

Finlay CJ (2001) The mosquito hypothetically considered as an agent of yellow fever transmission. 1881. Mil Med 166 (Sept Suppl) 5:6-10

Gladfelter WB (1982) White-band disease in Acropora palmata: implications for the structure and growth of shallow reefs. Bull Mar Sci 32:639-643

Green EP, Bruckner AW (2000) The significance of coral disease epizootiology for coral reef conservation. Biol Conserv 96:347-361

Goreau TJ, Cervino J, Goreau M, Hayes R and 14 others (1998) Rapid spread of Caribbean coral reef diseases. Rev Biol Trop 46:157-171

Harvell CD, Kim K, Burkholder JM, Colwell RR and 9 others (1999) Emerging marine diseases-climate links and anthropogenic factors. Science 285:1505-1510

Hildemann WH, Raison RL, Hull CJ, Akaka LK, Okamoto J, Cheung GP (1977) Tissue transplantation immunity in corals. Proc 3rd Int Coral Reef Symp 1:538-543

Knowlton N, Lang JC, Keller BD (1990) Case study of natural 
population collapse: post-hurricane predation on Jamaican staghorn corals. Smithson Contrib Mar Sci 31:25

Marsden JR (1962) A coral-eating polychaete. Nature 193:598

McCarthy M (2001) A century of the US Army yellow fever research. Lancet 357:1772

Miller MW, Baums IB, Williams DE, Szmant A (2002) Status of candidate coral, Acropora palmata, and its snail predator in the upper Florida Keys National Marine Sanctuary: 1998-2001. NOAA Tech Memo NMFS-SEFSC-479

Patterson KL, Porter JW, Ritchie KB, Polson SW, Mueller E, Peters EC, Santavy DL, Smith GW (2002) The etiology of white pox, a lethal disease of the Caribbean elkhorn coral, Acropora palmata. Proc Natl Acad Sci USA 99:8725-8730

Peters EC, Oprandy JJ, Yevich PP (1983) Possible causal agent of 'white band disease' in Caribbean acroporid corals. J Invertebr Pathol 41:394-396

Precht WF, Bruckner AW, Aronson RB, Bruckner RJ (2002) Endangered acroporid corals of the Caribbean. Coral Reefs 21:41-42

Reyes-Bonilla H, Calderon-Aguilera LE (1999) Population density, distribution and consumption rates of three corallivores at Cabo Pulmo Reef, Gulf of California, Mexico. Mar Ecol 20:347-357

Richardson LL (1998) Coral diseases: What is really known? Trends Ecol Evol 13:438-443

Ritchie KB, Smith GW (1995) Preferential carbon utilization by surface bacterial communities from water mass, normal and white-band diseased Acropora cervicornis. Mol Mar Biol Biotechnol 4:345-352

Ritchie KB, Smith GW (1998) Description of Type II white band disease in acroporid corals. Rev Biol Trop 46 (Suppl 5): 199-203

Editorial responsibility: Charles Birkeland (Contributing Editor), Honolulu, Hawaii, USA
Rodríguez-Martínez RE, Banaszak AT, Jordan-Dahlgren E (2001) Necrotic patches affect Acropora palmata (Scleractinia: Acroporidae) in the Mexican Caribbean. Dis Aquat Org 47:229-234

Santavy DL, Peters EC (1997) Microbial pests: coral disease in the Western Atlantic. Proc 8th Int Coral Reef Symp 1: $607-612$

Santavy DL, Peters EC, Kozlowski J, Wilkinson SS (1995) Characterization of the bacterium suspected in the incidence of white band disease. Abstr Gen Meet Am Soc Microbiol 95(N-1):332

StatSoft (2001) STATISTICA (data analysis software system), Version 6, Tulsa, OK. www.statsoft.com

Sussman M, Loya Y, Fine M, Rosenberg E (2003) The marine fireworm Hermodice carunculata is a winter reservoir and spring-summer vector for the coral-bleaching pathogen Vibrio shiloi. Environ Microbiol 5:250-256

Sutherland KP, Porter JW, Torres C (2004) Disease and immunity in Caribbean and Indo-Pacific zooxanthellate corals. Mar Ecol Prog Ser 266:273-302

Vollmer SV, Palumbi SR (2002) Hybridization and the evolution of reef coral diversity. Science 296:2023-2025

Ward J (1965) The digestive tract and its relation to feeding habits in the stenoglossan prosobranch Coralliophila abbreviata. Can J Zool 43:447-464

Williams DE, Miller MW (in press) Importance of disease and predation to the growth and survivorship of juvenile Acropora palmata and Acropora cervicornis: a demographic approach. Proc 10th Int Coral Reef Symp

Woodley C, Bruckner A, Galloway S, McLaughlin S, Downs C, Fauth J, Shott E, Larkin K (2003) Coral disease and health: a national research plan. NOAA, Silver Spring, MD

Submitted: December 3, 2003; Accepted: March 3, 2005

Proofs received from author(s): September 13, 2005 